\title{
Soil Cu contamination destroys the photosynthetic systems and hampers the growth of green vegetables
}

\author{
M.-Z. LIN ${ }^{*+}$ and M.-F. JIN ${ }^{* *}$ \\ Key Laboratory of Coastal Basin Environment, Fuqing Branch of Fujian Normal University, Fuqing, Fujian Province, \\ 350300, China* \\ School of Ocean Science and Biochemistry Engineering, Fuqing Branch of Fujian Normal University Fuqing, Fujian \\ Province 350300, China** \\ Fujian Provincial Key Laboratory of Eco-Industrial Green Technology (Wuyi University), Wuyishan, Fujian Province \\ 354300, China*
}

\begin{abstract}
Soil metal contamination leads to a decrease in a yield of crops and is a threat to human health. In the present study, the properties (i.e., photosynthetic pigments, gas-exchange parameters, chlorophyll fluorescence, biomass, leaf area, leaf mass per area) of three green vegetables (i.e., Brassica chinensis, Chrysanthemum coronarium, Brassica alboglabra) grown under various $\mathrm{Cu}$ treatments $\left[0,200,400\right.$, and $\left.600 \mathrm{mg}(\mathrm{Cu}) \mathrm{kg}^{-1}\right]$ were measured and analysed. The results showed that soil $\mathrm{Cu}$ contamination resulted in the damage of photosynthetic pigments, negative effects on gas exchange, and hampered growth of all three vegetables. However, it did not significantly influence PSII functions of the three vegetables. It indicates that soil $\mathrm{Cu}$ contamination negatively affected photosynthesis particularly due to stomatal factors, but not due to the damage of photosynthetic apparatus.
\end{abstract}

Additional key words: fluorescence kinetics; green vegetable; metal contamination; photosynthesis; soil Cu contamination.

\section{Introduction}

Soils are often polluted by metals due to developing industry (Chen et al. 2015) and agriculture (Zeng et al. 2007), and the population expansion (Meng et al. 2014). The investigation of heavy metal contents in soils is a basis for promoting the development of vegetable production with high quality and efficiency. Zeng et al. (2007) reported that $\mathrm{Zn}, \mathrm{Cr}$, and $\mathrm{Cu}$ occur in relatively high concentrations in lands utilized for the vegetable production, and that the highest concentration of $\mathrm{Cu}$ occurs in greenhouse soils. Heavy metal pollution in greenhouse soils becomes a serious problem (Zupančič 2016). Since $\mathrm{Cu}$ is not a biodegradable chemical, the manure containing $\mathrm{Cu}$, which is used in vegetable lands, brings a potential risk to soil causing $\mathrm{Cu}$ contamination (Lin et al. 2015). Although $\mathrm{Cu}$ is an essential element for plant growth and development, e.g., plays role in many physiological processes, such as photosynthesis, respiration, carbohydrate distribution, $\mathrm{N}$ reduction and fixation, protein metabolism, etc., it is toxic to plants at a high concentration, and an accumulation of $\mathrm{Cu}$ in agricultural products leads even to a threat to human health (Xu et al. 2006). Generally, the $\mathrm{Cu}$ content in leaves changes from 5 to $25 \mathrm{mg} \mathrm{kg}^{-1}$ (Huang 2004), and its content varies between $0.64-1.28 \mathrm{mg}(\mathrm{Cu}) \mathrm{l}^{-1}$ in human blood (Wang 2004).

Brassica chinensis is popular in southern China and southeast Asia. Being winter-hardy, Brassica varieties

Received 20 February 2017, accepted 10 January 2018, published as online-first 21 June 2018.

${ }^{+}$Corresponding author; e-mail: dragonlmz@163.com

Abbreviations: ABS/RC - absorption; Car - carotenoids; $\mathrm{Chl}$ - chlorophyll; $C_{\mathrm{i}}$ - intercellular $\mathrm{CO}_{2}$ concentration; $\mathrm{DF}_{\text {abs }}-\mathrm{driving}$ forces; $\mathrm{DI}_{0} / \mathrm{RC}$ - dissipation at $\mathrm{t}=0 ; E$ - transpiration rate; $\mathrm{ET}_{0} / \mathrm{RC}$ - electron transport at $\mathrm{t}=0 ; \mathrm{F}_{\mathrm{m}}$ - maximum Chl fluorescence intensity; $\mathrm{F}_{0}-$ minimum $\mathrm{Chl}$ fluorescence intensity; $\mathrm{F}_{\mathrm{v}} / \mathrm{F}_{\mathrm{m}}$ - maximum yield of PSII photochemistry; $g_{\mathrm{s}}$ - stomatal conductance; $\mathrm{HCu}-\mathrm{high} \mathrm{Cu}$ contamination; LA - leaf area; $\mathrm{LCu}$ - low $\mathrm{Cu}$ contamination; LMA - leaf mass per area; $\mathrm{MCu}$ - middle $\mathrm{Cu}$ contamination; OEC oxygen-evolving complex; $\mathrm{PI}_{\mathrm{abs}}$ - photosynthetic performance index; $P_{\mathrm{N}}$ - net photosynthetic rate; $\mathrm{Q}_{\mathrm{A}}$ - primary bound plastoquinone; $\mathrm{Q}_{\mathrm{B}}-$ secondary bound plastoquinone; $\mathrm{RC}$ - reaction center; $\mathrm{TR}_{0} / \mathrm{RC}-$ energy flux for trapping at $\mathrm{t}=0 ; \varphi \mathrm{E}_{0}-$ probability that an absorbed photon will move an electron into the electron transport chain; $\varphi \mathrm{P}_{0}$ - maximum quantum yield of primary photochemistry; $\psi \mathrm{E}_{0}-$ efficiency with which a trapped exciton can move an electron into the electron transport chain.

Acknowledgements: We thank three anonymous reviewers and the associate editor for their constructive comments that improved this manuscript. This study was partly supported by Natural Science Foundation of China (31370589) and the Open Project Program of Provincial Key Laboratory of Eco-Industrial Green Technology, Wuyi University. We would like to thank L.-R. Lin, A.-L. Liu, and L.-Y. Zhu, Fuqing Branch of Fujian Normal University, for their help in experiment. 
are increasingly grown in northern Europe. Considering convenience and practical factors, residents of suburban and urban areas in China often cultivate B. chinensis for their own consumption in nearby patches of idle lands (Fu and Wang 2015). Chrysanthemum coronarium is native to Mediterranean and Asia and used as a food and ornamental plant (Miyazawa and Alaoui 2015). C. coronarium is also used as traditional medicine due to its antibacterial activity (against Klebsiella pneumonia with low sensitivity) by its essential oil (Moussaoui and Alaoui 2016). Brassica alboglabra is native to coastal southern China and western Europe. B. alboglabra has become established as an important food crop plant because of its large food reserves and rich in essential nutrients (Guo et al. 2016). The above three green vegetables could provide carbohydrates, proteins, and less fat for human, they could also supply rich nutrients, e.g., vitamins $\mathrm{A}, \mathrm{C}, \mathrm{K}, \mathrm{B}_{6}$, folate, calcium, and calories. Therefore, farmers in southern China often cultivate the green vegetables as commercial agricultural products. Many farmers cultivate the green vegetables in a greenhouse. Thus, the effect of soil $\mathrm{Cu}$ contamination on the green vegetables becomes a serious scientific issue; e.g., Zeng et al. (2007) reported that the highest concentration of $\mathrm{Cu}$ occurs in greenhouse vegetable land soils comparing to other types of vegetable plantation land patterns. Additionally, soil metal contamination has been paid great attention in recent decades (Planquart et al. 1999, Lin et al. 2015, Zupančič 2016, Stolpe et al. 2017). However, in different countries, the limit values of soil heavy metal pollutants are different (Zeng et al. 2007). Researching on the effect of soil metal contamination on vegetables is a basis for assessment of heavy metal pollution in greenhouse soils (Zupančič 2016) and for allowing national governments to set soil pollution limits (Zeng et al. 2007).

The effect of metal(s) on plant has been widely reported, e.g., chromate on Spirodela polyrhiza (Susplugas

\section{Materials and methods}

Plant materials and pot-culture experiments: Seeds of the three green vegetables were purchased from Fuzhou Golden Seed Co., Ltd. (No. 495, Fuzhou, Fujian province, China). The pot-culture experiments were carried out in a greenhouse at the Fuqing Branch of Fujian Normal University from October to December in 2015. The potculture experiments were repeated twice. The seeds were sterilised with $0.1 \% \mathrm{HgCl}_{2}$ for $10 \mathrm{~min}$, followed by washing and soaking in distilled water for $8 \mathrm{~h}$, and then they were sown in sterilized silica culture. Then, one of plants with three leaves was transplanted into a pot (diameter: $200 \mathrm{~mm}$, height: $200 \mathrm{~mm}$ ) with about $2 \mathrm{~kg}$ soils. The properties of the soil (Lin et al. 2015) were: $\mathrm{pH} 6.4$, $2.24 \mathrm{~g}($ total $\mathrm{N}) \mathrm{kg}^{-1} 24.2 \mathrm{~g}$ (available $\left.\mathrm{N}\right) \mathrm{kg}^{-1}, 1.15 \mathrm{~g}$ (total P) $\mathrm{kg}^{-1}, 9.03 \mathrm{mg}$ (available P) $\mathrm{kg}^{-1}, 68 \mathrm{mg}$ (total potassium) $\mathrm{kg}^{-1}$, and $21.7 \%$ of clay particles. The soil $\mathrm{Cu}$ background value was $127.17 \mathrm{mg} \mathrm{kg}^{-1}$ (Lin et al. 2012a, et al. 2000, Appenroth et al. 2001), Cu on Oriza sativa (Xu et al. 2006), $\mathrm{Cu}$ on Lemna minor (Razinger et al. 2007), $\mathrm{Cd}, \mathrm{Cu}$ on Lemna minor (Razinger et al. 2010), $\mathrm{Cd}$ and $\mathrm{Cu}$ on Lemna minor (Razinger et al. 2012), heavy metals (Cu, $\mathrm{Cr}, \mathrm{Ni}$, etc.) on Wedelia trilobata (Lin et al. 2012a) or Alternanthera philoxeroides (Lin et al. 2012b), $\mathrm{Cd}$ on $W$. trilobata (Shi et al. 2014), $\mathrm{Pb}$ on B. chinensis (Fu and Wang 2015, Tang et al. 2015). The pollutants commonly significantly affect glutathinone, antioxidant enzymes, glutathione reductase, guaiacol peroxidase, and catalase in plants (e.g., Razinger et al. 2007). It is also known that photosynthesis is inhibited by heavy metals, and PSII is considered as the main target of heavy metals (Susplugas et al. 2000, Appenroth et al. 2001). Chlorophyll (Chl) fluorescence of plants changes after exposure to $\mathrm{Cu}$ (Razinger et al. 2007, 2010, 2012).

However, up till now, not much is known about the toxic effect of $\mathrm{Cu}$ on three common green vegetables (B. chinensis, C. coronarium, B. alboglabra). Because of this limited knowledge, in the present study, we focused on the physio-ecological index [i.e., pigments, net photosynthetic rate $\left.\left(P_{\mathrm{N}}\right)\right]$ and the plant growth properties [i.e., leaf biomass, leaf area (LA), and leaf mass per area (LMA)] of the three vegetables grown in soil with varying degree of $\mathrm{Cu}$ contamination by pot-culture experiments. We also focused on the alteration and function of PSII through analysis of the Chl $a$ fluorescence transient in the vegetables grown at different $\mathrm{Cu}$ concentrations by potculture experiments. We also analysed gas-exchange characteristics, such as stomatal conductance $\left(g_{\mathrm{s}}\right)$ and the intercellular $\mathrm{CO}_{2}$ concentration $\left(C_{\mathrm{i}}\right)$, in the plants grown at varying degrees of soil $\mathrm{Cu}$ contamination. Our results may provide not only a basis for understanding the effect of pollutant on a process of photosynthesis in vegetables, but a robust basis for vegetable land soils management, especially, for greenhouse soils.

$2012 b)$. In order to simulate the pollution of soil, three $\mathrm{Cu}$ treatments were designed according to Chinese environmental quality standard for soils (GB 15618-1995). Before being filled into pots, air-dried soil was added with 0 (as control), 200 (low $\mathrm{Cu}$ contamination, $\mathrm{LCu}$ ), 400 (middle $\mathrm{Cu}$ contamination, $\mathrm{MCu}$ ), or $600 \mathrm{mg} \mathrm{kg}^{-1}$ (high $\mathrm{Cu}$ contamination, $\mathrm{HCu}$ ) of $\mathrm{CuSO}_{4} \cdot 5 \mathrm{H}_{2} \mathrm{O}$. Each treatment had 15 replicates.

Photosynthetic pigments: Measurements of photosynthetic pigments were performed with three replicates on 10 December 2015. Photosynthetic pigments were extracted according to Arnon (1949). Fresh leaf (the third from bottom) samples $(0.2 \mathrm{~g})$, which were randomly selected, were ground using mortar and pestle in $20 \mathrm{ml}$ of $80 \%$ acetone $(\mathrm{v} / \mathrm{v})$, and then filtered through No. 2 Whatman filter paper. Chl $a, \mathrm{Chl} b$, carotenoids (Car), and 
total pigments were measured at 470,646, and $663 \mathrm{~nm}$, using UV spectrophotometer Model 1801 (Beifen-Ruili Analycital Instrument Co. Ltd, Beijing, China) according to Lichtenthaler and Wellburn (1983).

Photosynthetic capacity: The measurements of photosynthetic capacity were performed twice (corresponding to two pot-culture experiments). Each time, seven healthy and fully developed leaves (the third from bottom) were randomly selected in order to measure photosynthetic capacity. The $P_{\mathrm{N}}$ [irradiance of $1,000 \mu \mathrm{mol}$ (photon) $\mathrm{m}^{-2} \mathrm{~s}^{-1}$, $25^{\circ} \mathrm{C}$, and $360-380 \mathrm{ppm} \mathrm{CO}_{2}$ ] was monitored on the leaf with CIRAS-2 portable photosynthesis system (PP Systems, USA) with an LED radiation source. Once the steady state was reached, recording was made and stored. At the same time, the $C_{\mathrm{i}}, g_{\mathrm{s}}$, and transpiration rate $(E)$ were recorded. The measurement of photosynthetic capacity was performed between 9:00 and 16:00 h (solar time).

Chl $\boldsymbol{a}$ fluorescence and JIP: In the second pot-culture experiments, seven healthy and fully developed leaves (the third from bottom) were randomly selected per treatment in order to measure $\mathrm{Chl} a$ fluorescence. Chl $a$ fluorescence was measured at room temperature $\left(22^{\circ} \mathrm{C}\right)$ using a plant efficiency analyser (Handy-PEA fluorometer, Hansatech Instruments, UK) with protocol [i.e., the sample was illuminated with 2-s pulse of excitation light intensity of 3,000 $\mu \mathrm{mol}$ (photon) $\mathrm{m}^{-2} \mathrm{~s}^{-1}$ ] from 8 to 10 December 2015 . Leaves were adapted in darkness for $20 \mathrm{~min}$ before measurements. The $\mathrm{F}_{0}$ (minimum $\mathrm{Chl}$ fluorescence intensity), $F_{m}$ (maximum $C h l$ fluorescence intensity), $F_{v} / F_{m}$ (maximum yield of photochemistry, where $\mathrm{F}_{\mathrm{v}}=\mathrm{F}_{\mathrm{m}}-\mathrm{F}_{0}$ ) were recorded and stored. At the same time, $\mathrm{PI}_{\mathrm{abs}}$ (photosynthetic performance index), $\varphi \mathrm{E}_{0}$ (probability that an absorbed photon will move an electron into the electron transport chain), $\varphi \mathrm{P}_{0}$ (maximum quantum yield of primary photochemistry), $\psi \mathrm{E}_{0}$ (efficiency with which a trapped

\section{Results}

Photosynthetic pigments: Concentrations of Chl $a$ and total pigments of $\mathrm{Cu}$-contaminated plants were all lower than that of control (Fig. 1). Overall, all of the Chl $a$ and total pigments declined along with increasing soil $\mathrm{Cu}$ contamination. In B. chinensis, the concentrations of $\mathrm{Chl} b$ and $\mathrm{Car}$ in $\mathrm{Cu}$-contaminated groups were also all lower than that of control. The concentrations of Car showed no difference between the $\mathrm{LCu}\left(200 \mathrm{mg} \mathrm{kg}^{-1}\right)$ and the control, or between the $\mathrm{MCu}\left(400 \mathrm{mg} \mathrm{kg}^{-1}\right)$ and the $\mathrm{HCu}(600 \mathrm{mg}$ $\mathrm{kg}^{-1}$ ), however, the concentrations of $\mathrm{Car}$ in the $\mathrm{MCu}$ and $\mathrm{HCu}$ were both different from the $\mathrm{LCu}$ or the control. In $C$. coronarium, the concentrations of $\mathrm{Chl} b$ in $\mathrm{Cu}-$ contaminated groups were also all significantly lower than that of control. Overall, the concentrations of $\mathrm{Chl} b$ declined with increasing soil $\mathrm{Cu}$ contamination, however, the concentrations of Car ascended along with increasing soil $\mathrm{Cu}$. And, the concentrations of Car were not different exciton can move an electron into the electron transport chain), $\mathrm{ABS} / \mathrm{RC}$ (absorption), $\mathrm{ET}_{0} / \mathrm{RC}$ (electron transport at $\mathrm{t}=0), \mathrm{DI}_{0} / \mathrm{RC}($ dissipation at $\mathrm{t}=0), \mathrm{TR}_{0} / \mathrm{RC}($ energy flux for trapping at $\mathrm{t}=0$ ), and $\mathrm{DF}_{\mathrm{abs}}$ (driving forces) were recorded and stored. Fluorescence measurements were performed around noon (11:00-12:00 h, solar time). At the same time, the JIP-test was performed. All the fluorescence transients were recorded in a time span from $10 \mu \mathrm{s}$ to $2 \mathrm{~s}$ with a data acquisition rate of $10 \mu \mathrm{s}$ for $2 \mathrm{~s}$. Detailed JIP-test see Susplugas et al. (2000) or Appenroth et al. (2001).

Biomass, LA and LMA: Seven plants were randomly selected to measure biomass, LA and LMA. LA was measured based on image processing according to Lü et al. (2010). Leaf image segmentation was implemented using scanner (HP LaserJet 1536dnf MFP, Guangzhou, China). The LA calculation equation is as follows:

$$
\mathrm{LA}=\mathrm{Sf} \times \frac{\mathrm{Pl}}{\mathrm{Pf}}
$$

where, Sf denotes the square, $\mathrm{Pl}$ denotes the pixel number of leaf object in the image, and Pf denotes the pixel number within the square in the image. Leaf samples were dried at $65^{\circ} \mathrm{C}$ until no further reduction in mass, and the dry mass (DW) was measured by weighting method. The following equation was applied to estimate LMA:

$$
\mathrm{LMA}=\frac{\mathrm{DW}}{\mathrm{LA}}
$$

Statistical analysis: One-way analysis of variance (ANOVA) was conducted with the SPSS 16.0. The data ( \pm standard error) were tested for normality (KolmogorovSmirnov's test) and homogeneity (Levin's test). Evaluation of significance of the data between the groups of tested parameters was done through Duncan's test $(P<0.05)$.

between $\mathrm{LCu}, \mathrm{MCu}$ groups and the control, but remarkably increased in the $\mathrm{HCu}$ group. In $B$. alboglabra, the concentrations of $\mathrm{Chl} b$ decreased with increasing soil $\mathrm{Cu}$ contamination, but the $\mathrm{HCu}\left(600 \mathrm{mg} \mathrm{kg}^{-1}\right)$. The concentration of Car was not significantly affected by soil $\mathrm{Cu}$ contamination.

Gas-exchange parameters: Compared with the control, all $P_{\mathrm{N}}$ declined in the $\mathrm{Cu}$-contaminated groups (Table 1). With increasing soil $\mathrm{Cu}$ contamination, all $P_{\mathrm{N}}$ showed apparently decreasing trends. The $E$ of $C$. coronarium showed no significant difference between the control and different $\mathrm{Cu}$-contaminated groups. The $E$ of $B$. chinensis and $B$. alboglabra both showed no consistent upward or downward trends with increasing $\mathrm{Cu}$ contamination. The $g_{\mathrm{s}}$ showed consistent downward trend with the increasing $\mathrm{Cu}$ contamination. With the increasing $\mathrm{Cu}$ contamination, 


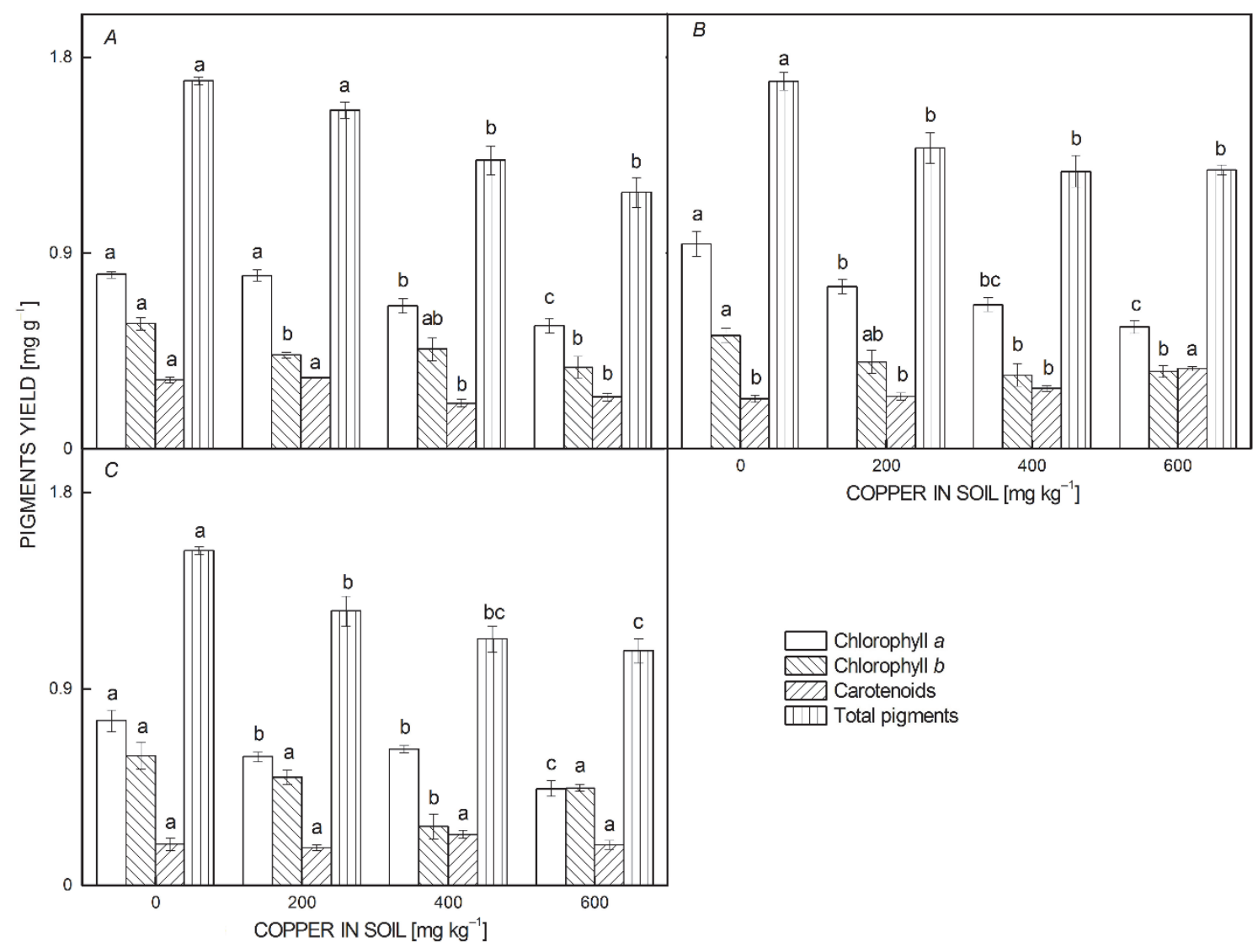

Fig. 1. Effects of soil $\mathrm{Cu}$ contamination on the pigment contents of Brassica chinensis (A), Chrysanthemum coronarium (B), and Brassica alboglabra $(C)$. Different lowercase letters show significant difference between different Cu-contaminated groups at $P<0.05$, and, error bars show standard error (SE), $n=3$.

the $C_{\mathrm{i}}$ also showed consistent downward trends, except for the data measured in $B$. chinesis on 3 November, and except for the data measured in B. alboglabra on 4 November 2015.

Chl fluorescence: The parameters of Chl $a$ fluorescence changed with increasing $\mathrm{Cu}$ contamination, but the change had no statistical significance (Fig. 2). In B. alboglabra, with increasing soil $\mathrm{Cu}$ contamination, the $\mathrm{PI}_{\mathrm{abs}}, \mathrm{F}_{0}, \mathrm{~F}_{\mathrm{m}}, \mathrm{F}_{\mathrm{v}}$, $\mathrm{F}_{\mathrm{v}} / \mathrm{F}_{\mathrm{m}}, \varphi \mathrm{P}_{0}, \varphi \mathrm{E}_{0}, \psi \mathrm{E}_{0}, \mathrm{DF}_{\text {abs }}$ all declined in the $\mathrm{MCu}$ plants compared with the control; most of parameters slightly increased at the $\mathrm{HCu}$. The $\mathrm{ABS} / \mathrm{RC}$ showed consistent upward trends; the $\mathrm{TR}_{0} / \mathrm{RC}$ and $\mathrm{DI}_{0} / \mathrm{RC}$ all increased from the control to $\mathrm{MCu}$, but declined again at the $\mathrm{HCu}$. $\mathrm{ET}_{0} / \mathrm{RC}$ and $\mathrm{F}_{\mathrm{v}} / \mathrm{F}_{\mathrm{m}}$ did not show any consistent trends. It indicates that the values of Chl $a$ fluorescence parameters were not significantly different between control and $\mathrm{Cu}$ contaminated plants.

OJIP: All leaves showed normal Chl $a$ fluorescence, OJIP transient, and the curve started from the initial $\mathrm{F}_{0}$ intensity and increased to a peak of $\mathrm{P}$ or $\mathrm{F}_{\mathrm{m}}$ (Susplugas et al. 2000, Appenroth et al. 2001). Two intermediate steps J (about $2 \mathrm{~ms}$ ) and I (about $30 \mathrm{~ms}$ ) appeared between $\mathrm{O}$ and $\mathrm{P}$.
A decrease in the $\mathrm{F}_{\mathrm{m}}$ level appeared in B. alboglabra and C. coronarium in $\mathrm{Cu}$-contaminated plants (Fig. 3). On the contrary, an increase in the $\mathrm{F}_{\mathrm{m}}$ level could be seen in $B$. chinensis at the $\mathrm{Cu}$ contamination. It verified that the photosynthetic apparatus of all three vegetables was not significantly influenced by the soil $\mathrm{Cu}$ contamination.

Biomass, LA and LMA: The effects of soil $\mathrm{Cu}$ contamination on the biomass are shown in Fig. $4 A$. $\mathrm{LCu}$ and $\mathrm{MCu}$ (200 and $400 \mathrm{mg} \mathrm{kg}^{-1}$, respectively) contamination had promoted the biomass of $C$. coronarium compared with the control, however, the $\mathrm{HCu}\left(600 \mathrm{mg} \mathrm{kg}^{-1}\right)$ decreased the biomass of $C$. coronarium. The $\mathrm{LCu}\left(200 \mathrm{mg} \mathrm{kg}^{-1}\right)$ increased the biomass of $B$. chinensis compared with the control, but without any statistical significance. The biomass of B. chinensis and B. alboglabra both showed downward trends with the increasing $\mathrm{Cu}$ contamination. The biomass of $B$. chinensis at $\mathrm{HCu}$ significantly decreased.

The effects of soil $\mathrm{Cu}$ contamination on the LA of vegetables are shown in Fig. $4 B$. The LA of $C$. coronarium and B. alboglabra both increased at the $\mathrm{LCu}$ compared with the control, but it had no statistical significance. LA of all plant types descended with the increasing $\mathrm{Cu}$ 
Table 1. Effects of soil $\mathrm{Cu}$ contamination on gas-exchange parameters of vegetables. $E$ - transpiration rate, $g_{\mathrm{s}}-$ stomatal conductance, $P_{\mathrm{N}}-$ net photosynthetic rate, $C_{\mathrm{i}}-$ intercellular $\mathrm{CO}_{2}$ concentration. Data show means $\pm \mathrm{SE}$ and at the same row, the differential lowercase letters indicate differ significantly at $P<0.05, n=7$.

\begin{tabular}{|c|c|c|c|c|c|c|}
\hline \multirow[t]{2}{*}{ Species } & \multirow[t]{2}{*}{ Date } & \multirow[t]{2}{*}{ Gas-exchange parameter } & \multicolumn{4}{|c|}{$\mathrm{Cu}$ exposure $\left[\mathrm{mg} \mathrm{kg}^{-1}\right.$ (soil)] } \\
\hline & & & $0 \mathrm{mg} \mathrm{kg}^{-1}$ & $200 \mathrm{mg} \mathrm{kg}^{-1}$ & $400 \mathrm{mg} \mathrm{kg}^{-1}$ & $600 \mathrm{mg} \mathrm{kg}^{-1}$ \\
\hline \multirow[t]{8}{*}{ C. coronarium } & \multirow[t]{4}{*}{$2^{\text {nd }}$ Nov. } & $P_{\mathrm{N}}\left[\mu \mathrm{mol}\left(\mathrm{CO}_{2}\right) \mathrm{m}^{-2} \mathrm{~s}^{-1}\right]$ & $10.0 \pm 0.7^{\mathrm{a}}$ & $9.4 \pm 0.4^{\mathrm{a}}$ & $9.7 \pm 0.6^{\mathrm{a}}$ & $8.8 \pm 0.6^{\mathrm{a}}$ \\
\hline & & $E\left[\mathrm{mmol}\left(\mathrm{H}_{2} \mathrm{O}\right) \mathrm{m}^{-2} \mathrm{~s}^{-1}\right]$ & $2.8 \pm 0.2^{\mathrm{a}}$ & $3.0 \pm 0.2^{\mathrm{a}}$ & $2.7 \pm 0.3^{\mathrm{a}}$ & $2.0 \pm 0.2^{b}$ \\
\hline & & $g_{\mathrm{s}}\left[\mathrm{mmol}\left(\mathrm{H}_{2} \mathrm{O}\right) \mathrm{m}^{-2} \mathrm{~s}^{-1}\right]$ & $2,153.4 \pm 701.4^{\mathrm{a}}$ & $1,437.4 \pm 390.1^{\mathrm{ab}}$ & $944.1 \pm 236.0^{\mathrm{b}}$ & $447.4 \pm 77.0^{b}$ \\
\hline & & $C_{\mathrm{i}}\left[\mu \mathrm{mol}\left(\mathrm{CO}_{2}\right) \mathrm{mol}^{-1}\right]$ & $360.6 \pm 3.1^{\mathrm{a}}$ & $362.3 \pm 3.1^{\mathrm{ab}}$ & $346.3 \pm 7.8^{\mathrm{bc}}$ & $339.1 \pm 5.7^{\mathrm{c}}$ \\
\hline & \multirow[t]{4}{*}{$8^{\text {th }}$ Dec. } & $P_{\mathrm{N}}\left[\mu \mathrm{mol}\left(\mathrm{CO}_{2}\right) \mathrm{m}^{-2} \mathrm{~s}^{-1}\right]$ & $12.9 \pm 1.6^{\mathrm{a}}$ & $7.3 \pm 0.4^{\mathrm{b}}$ & $6.6 \pm 0.4^{\mathrm{b}}$ & $8.0 \pm 1.0^{\mathrm{b}}$ \\
\hline & & $E\left[\mathrm{mmol}\left(\mathrm{H}_{2} \mathrm{O}\right) \mathrm{m}^{-2} \mathrm{~s}^{-1}\right]$ & $2.9 \pm 0.2^{\mathrm{a}}$ & $3.0 \pm 0.1^{\mathrm{a}}$ & $3.0 \pm 0.1^{\mathrm{a}}$ & $3.1 \pm 0.1^{\mathrm{a}}$ \\
\hline & & $g_{\mathrm{s}}\left[\mathrm{mmol}\left(\mathrm{H}_{2} \mathrm{O}\right) \mathrm{m}^{-2} \mathrm{~s}^{-1}\right]$ & $2,120.9 \pm 1,300.1^{\mathrm{a}}$ & $953.9 \pm 92.8^{a}$ & $982.7 \pm 61.9^{\mathrm{a}}$ & $866.1 \pm 63.7^{\mathrm{a}}$ \\
\hline & & $C_{\mathrm{i}}\left[\mu \mathrm{mol}\left(\mathrm{CO}_{2}\right) \mathrm{mol}^{-1}\right]$ & $391.6 \pm 7.4^{\mathrm{a}}$ & $381.9 \pm 2.0^{\mathrm{a}}$ & $381.1 \pm 1.7^{\mathrm{a}}$ & $373.6 \pm 3.6^{\mathrm{a}}$ \\
\hline \multirow[t]{8}{*}{ B. chinensis } & \multirow[t]{4}{*}{$3^{\text {rd }}$ Nov. } & $P_{\mathrm{N}}\left[\mu \mathrm{mol}\left(\mathrm{CO}_{2}\right) \mathrm{m}^{-2} \mathrm{~s}^{-1}\right]$ & $17.4 \pm 1.1^{\mathrm{a}}$ & $8.2 \pm 0.7^{\mathrm{c}}$ & $11.4 \pm 0.9^{\mathrm{b}}$ & $6.3 \pm 1.1^{\mathrm{c}}$ \\
\hline & & $E\left[\mathrm{mmol}\left(\mathrm{H}_{2} \mathrm{O}\right) \mathrm{m}^{-2} \mathrm{~s}^{-1}\right]$ & $1.0 \pm 0.2^{\mathrm{ab}}$ & $0.6 \pm 0.0^{\mathrm{b}}$ & $1.2 \pm 0.1^{\mathrm{a}}$ & $0.7 \pm 0.1^{\mathrm{b}}$ \\
\hline & & $g_{\mathrm{s}}\left[\mathrm{mmol}\left(\mathrm{H}_{2} \mathrm{O}\right) \mathrm{m}^{-2} \mathrm{~s}^{-1}\right]$ & $274.4 \pm 98.3^{\mathrm{a}}$ & $101.0 \pm 9.2^{\mathrm{b}}$ & $253.9 \pm 32.0^{\mathrm{ab}}$ & $115.4 \pm 13.7^{\mathrm{ab}}$ \\
\hline & & $C_{\mathrm{i}}\left[\mu \mathrm{mol}\left(\mathrm{CO}_{2}\right) \mathrm{mol}^{-1}\right]$ & $215.6 \pm 51.0^{\mathrm{c}}$ & $267.0 \pm 7.4^{b}$ & $309.6 \pm 7.6^{\mathrm{a}}$ & $300.4 \pm 20.1^{\mathrm{a}}$ \\
\hline & \multirow[t]{4}{*}{$9^{\text {th }}$ Dec. } & $P_{\mathrm{N}}\left[\mu \mathrm{mol}\left(\mathrm{CO}_{2}\right) \mathrm{m}^{-2} \mathrm{~s}^{-1}\right]$ & $14.3 \pm 1.1^{\mathrm{a}}$ & $10.6 \pm 0.8^{\mathrm{b}}$ & $8.3 \pm 0.4 b^{c}$ & $6.9 \pm 1.1^{\mathrm{c}}$ \\
\hline & & $E\left[\mathrm{mmol}\left(\mathrm{H}_{2} \mathrm{O}\right) \mathrm{m}^{-2} \mathrm{~s}^{-1}\right]$ & $2.5 \pm 0.1^{\mathrm{a}}$ & $2.0 \pm 0.1^{\mathrm{b}}$ & $2.2 \pm 0.1^{\mathrm{ab}}$ & $2.1 \pm 0.1^{b}$ \\
\hline & & $g_{\mathrm{s}}\left[\mathrm{mmol}\left(\mathrm{H}_{2} \mathrm{O}\right) \mathrm{m}^{-2} \mathrm{~s}^{-1}\right]$ & $826.9 \pm 103.0^{\mathrm{a}}$ & $557.7 \pm 80.6^{b}$ & $719.4 \pm 58.8^{\mathrm{ab}}$ & $604.0 \pm 41.1^{\mathrm{b}}$ \\
\hline & & $C_{\mathrm{i}}\left[\mu \mathrm{mol}\left(\mathrm{CO}_{2}\right) \mathrm{mol}^{-1}\right]$ & $373.3 \pm 2.1^{\mathrm{a}}$ & $354.7 \pm 4.6^{\mathrm{c}}$ & $363.7 \pm 1.4^{\mathrm{bc}}$ & $366.1 \pm 4.1^{\mathrm{a}}$ \\
\hline \multirow[t]{8}{*}{ B. alboglabra } & \multirow[t]{4}{*}{$4^{\text {th }}$ Nov. } & $P_{\mathrm{N}}\left[\mu \mathrm{mol}\left(\mathrm{CO}_{2}\right) \mathrm{m}^{-2} \mathrm{~s}^{-1}\right]$ & $16.5 \pm 0.6^{\mathrm{a}}$ & $12.8 \pm 0.7^{\mathrm{b}}$ & $10.8 \pm 1.2^{\mathrm{b}}$ & $11.9 \pm 0.6^{\mathrm{b}}$ \\
\hline & & $E\left[\mathrm{mmol}\left(\mathrm{H}_{2} \mathrm{O}\right) \mathrm{m}^{-2} \mathrm{~s}^{-1}\right]$ & $0.9 \pm 0.1^{b}$ & $1.3 \pm 0.1^{\mathrm{a}}$ & $1.1 \pm 0.0^{\mathrm{a}}$ & $1.1 \pm 0.0^{\mathrm{a}}$ \\
\hline & & $g_{\mathrm{s}}\left[\mathrm{mmol}\left(\mathrm{H}_{2} \mathrm{O}\right) \mathrm{m}^{-2} \mathrm{~s}^{-1}\right]$ & $326.7 \pm 39.5^{\mathrm{c}}$ & $756.7 \pm 77.5^{\mathrm{a}}$ & $481.9 \pm 23.9^{b}$ & $467.0 \pm 31.6^{b}$ \\
\hline & & $C_{\mathrm{i}}\left[\mu \mathrm{mol}\left(\mathrm{CO}_{2}\right) \mathrm{mol}^{-1}\right]$ & $326.0 \pm 4.1^{\mathrm{c}}$ & $359.3 \pm 4.7^{\mathrm{a}}$ & $347.7 \pm 5.4^{\mathrm{ab}}$ & $342.0 \pm 3.5^{\mathrm{b}}$ \\
\hline & \multirow[t]{4}{*}{$10^{\text {th }}$ Dec. } & $P_{\mathrm{N}}\left[\mu \mathrm{mol}\left(\mathrm{CO}_{2}\right) \mathrm{m}^{-2} \mathrm{~s}^{-1}\right]$ & $14.8 \pm 1.3^{\mathrm{a}}$ & $11.7 \pm 1.0^{\mathrm{ab}}$ & $9.0 \pm 1.6^{\mathrm{bc}}$ & $6.1 \pm 0.5^{\mathrm{c}}$ \\
\hline & & $E\left[\mathrm{mmol}\left(\mathrm{H}_{2} \mathrm{O}\right) \mathrm{m}^{-2} \mathrm{~s}^{-1}\right]$ & $3.8 \pm 0.3^{\mathrm{a}}$ & $2.4 \pm 0.2^{\mathrm{b}}$ & $1.8 \pm 0.3^{\mathrm{bc}}$ & $1.3 \pm 0.1^{\mathrm{c}}$ \\
\hline & & $g_{\mathrm{s}}\left[\mathrm{mmol}\left(\mathrm{H}_{2} \mathrm{O}\right) \mathrm{m}^{-2} \mathrm{~s}^{-1}\right]$ & $705.9 \pm 133.0^{\mathrm{a}}$ & $287.4 \pm 42.9^{b}$ & $199.4 \pm 36.3^{\mathrm{b}}$ & $179.3 \pm 22.9^{b}$ \\
\hline & & $C_{\mathrm{i}}\left[\mu \mathrm{mol}\left(\mathrm{CO}_{2}\right) \mathrm{mol}^{-1}\right]$ & $354.7 \pm 6.8^{\mathrm{a}}$ & $314.6 \pm 11.1^{\mathrm{b}}$ & $304.4 \pm 5.5^{\mathrm{b}}$ & $320.7 \pm 7.8^{b}$ \\
\hline
\end{tabular}

contamination, and the LA of $C$. coronarium and B. chinensis at $\mathrm{HCu}$ significantly decreased.

The effects of soil $\mathrm{Cu}$ contamination on the LMA are shown in Fig. 4C. The LMA of $C$. coronarium and B. alboglabra were not significantly affected by $\mathrm{Cu}$ contamination. The LMA of $B$. chinensis at $\mathrm{MCu}$ and $\mathrm{HCu}$ significantly decreased.

\section{Discussion}

Photosynthetic pigments: Heavy metals reduce accumulation of photosynthetic pigments (Rai et al. 2016). At a cellular level, an excess of heavy metals can cause damage leading to the formation of reactive oxygen radicals or the interaction with proteins impairing key cellular processes (e.g., photosynthesis), inactivating enzymes, and disturbing protein structure (Rai et al. 2016, Vilas et al. 2016). Chl content is indicative of the plant metabolisms efficiency and health status, whereas Car plays a major role in photoprotection and defending plant cell from oxidative stress (Kopsell et al. 2007). Photosynthetic pigments are useful for stress resistance and may be partly disappeared because that they participate in radical ions elimination and energy dissipation (Wilson et al. 2006).

Previous studies have shown that pollutants lead to
It indicates that soil $\mathrm{Cu}$ contamination significantly decreased the yields of $B$. chinensis and $C$. coronarium at high $\mathrm{Cu}$ concentrations and significantly increased the yields of $C$. coronarium at low $\mathrm{Cu}$ concentrations. The $B$. alboglabra was insensitive to the soil $\mathrm{Cu}$ contaminations, which did not exceed the soil pollution limits.

decrease in the content of photosynthetic pigments. Cadmium $\left(\mathrm{Cd}^{2+}\right)$ induces changes in the composition and structure of the light-harvesting complex II (Krupa et al. 1988). $\mathrm{Cu}^{2+}$ causes a slower $\mathrm{Chl}$ incorporation into PSI and PSII in greening barley seedlings (Capsi et al. 1999). The Chl biosynthesis is affected by heavy metals as it substitutes $\mathrm{Mg}^{2+}$ in Chl (Rai et al. 2016). In the present study, the results showed that soil $\mathrm{Cu}$ contamination resulted in the decline of photosynthetic pigments (Fig. 1). Our results are similar to the previous reports (Capsi et al. 1999, Rai et al. 2016, Vilas et al. 2016). Our results also showed that the ratio of Chl $a / b$ of B. alboglabra and $C$. coronarium showed downward trends with the increasing $\mathrm{Cu}$ contamination. 

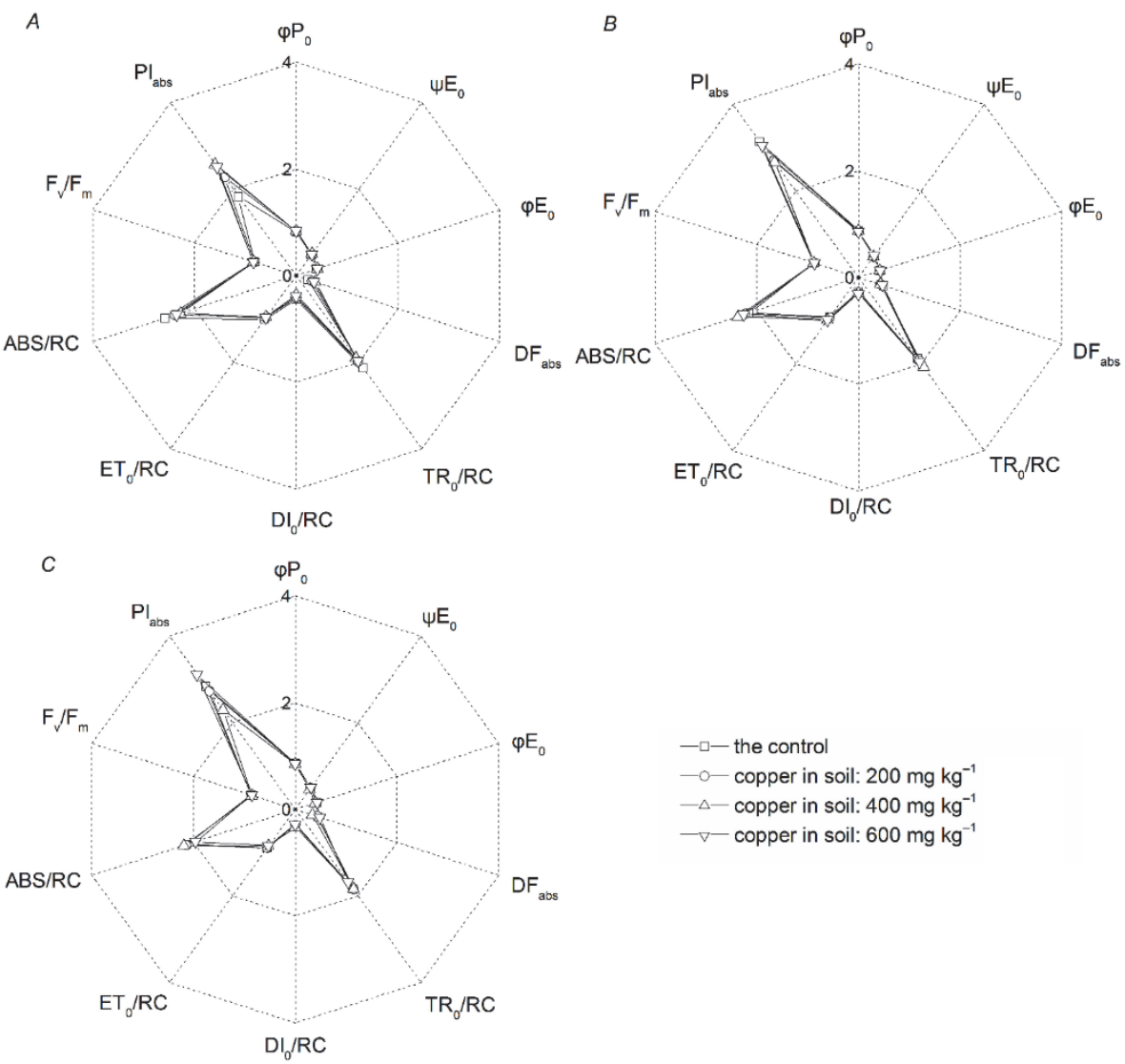

Fig. 2. Spider plot showing selected JIP-test parameters of Brassica chinensis (A), Chrysanthemum coronarium (B), and Brassica alboglabra $(C)$ in different $\mathrm{Cu}$-contaminated groups.

Photosynthesis: $\mathrm{Cu}$ contamination results in decreasing $P_{\mathrm{N}}$ in plants, e.g., in cucumber (Vinit-Dunand et al. 2002), W. trilobata (Lin et al. 2015), and Oryza sativa (Costa and Sharma 2016). Pollutants have direct effect on plants by affecting PSII and PSI and indirect effect on photosynthesis (Rai et al. 2016). In the present study, the results showed that all $P_{\mathrm{N}}$ at different $\mathrm{Cu}$-contaminated groups were lower than that of the control, and overall, all $P_{\mathrm{N}}$ showed a downward trend with respect to the increasing of soil $\mathrm{Cu}$ contamination (Table 1). It is in line with the previous studies (Lin et al. 2015, Costa and Sharma 2016, Rai et al. 2016).

The degree of photosynthesis often declines due to stomatal factors. The decline of photosynthesis usually occurs in plants under low water stress or high-temperature stress, with respect to the downregulation of $g_{\mathrm{s}}$ for reducing moisture loss in leaves. Stomatal closure usually occurs in plants under other abiotic stresses, e.g., organic or inorganic pollution. However, Vinit-Dunand et al. (2002) found that the $P_{\mathrm{N}}$ of cucumber plants decline at a nearly constant $C_{\mathrm{i}}$ which indicates that stomatal closure does not account for the inhibition of photosynthesis under $\mathrm{Cu}$ contamination. In the present study, the results showed that generally the $C_{\mathrm{i}}$ of $C$. coronarium and B. alboglabra declined due to the soil $\mathrm{Cu}$ contamination and the $g_{\mathrm{s}}$ of the three vegetables also showed a downward trend due to the soil $\mathrm{Cu}$ contamination except for the $B$. alboglabra assessed on 4 November 2015 (Table 1). It suggests that the decreasing $P_{\mathrm{N}}$ of the three vegetables due to stomatal factor resulted from the soil $\mathrm{Cu}$ contamination. Pollutants also lead to a remarkable decrease in total free amino acids (Chen et al. 2001). Soil $\mathrm{Cu}$ contamination might lead to metabolic limitations and result in accumulation of signaling molecules, e.g., abscisic acid (Chen et al. 2001), thus inducing the stomatal closure (Mishra et al. 2006), because the hormone, abscisic acid, regulates the opening and closing of stomata (Mishra et al. 2006).

Chl $\boldsymbol{a}$ fluorescence: Pollutants usually negatively impact on the PSII. Heavy metals (e.g., $\mathrm{Cu}$ and $\mathrm{Pb}$ ) are directly involved in electron transport and disturb electron transport in light reactions and affect various enzymes in dark reactions (Rai et al. 2016). Cu contamination may inactivate the PSII reaction centers (RC) in Chlorella pyrenoidosa and inhibit the electron transport on the acceptor side (Xia and Tian 2009). The ABS/RC increases with increasing $\mathrm{Cu}$ contamination, but the $\mathrm{ET}_{0} / \mathrm{RC}$ decreases, and excess $\mathrm{Cu}$ has an insignificant effect on the $\mathrm{TR}_{0} / \mathrm{RC}$ (Xia and Tian 2009). $\mathrm{F}_{0}, \mathrm{~F}_{\mathrm{m}}, \mathrm{F}_{\mathrm{v}} / \mathrm{F}_{\mathrm{m}}, \varphi \mathrm{P}_{0}, \varphi \mathrm{E}_{0}, \psi \mathrm{E}_{0}$, $\mathrm{ABS} / \mathrm{RC}, \mathrm{TR}_{0} / \mathrm{RC}, \mathrm{ET}_{0} / \mathrm{RC}, \mathrm{DI}_{0} / \mathrm{RC}$, and $\mathrm{PI}_{\mathrm{abs}}$ are affected 


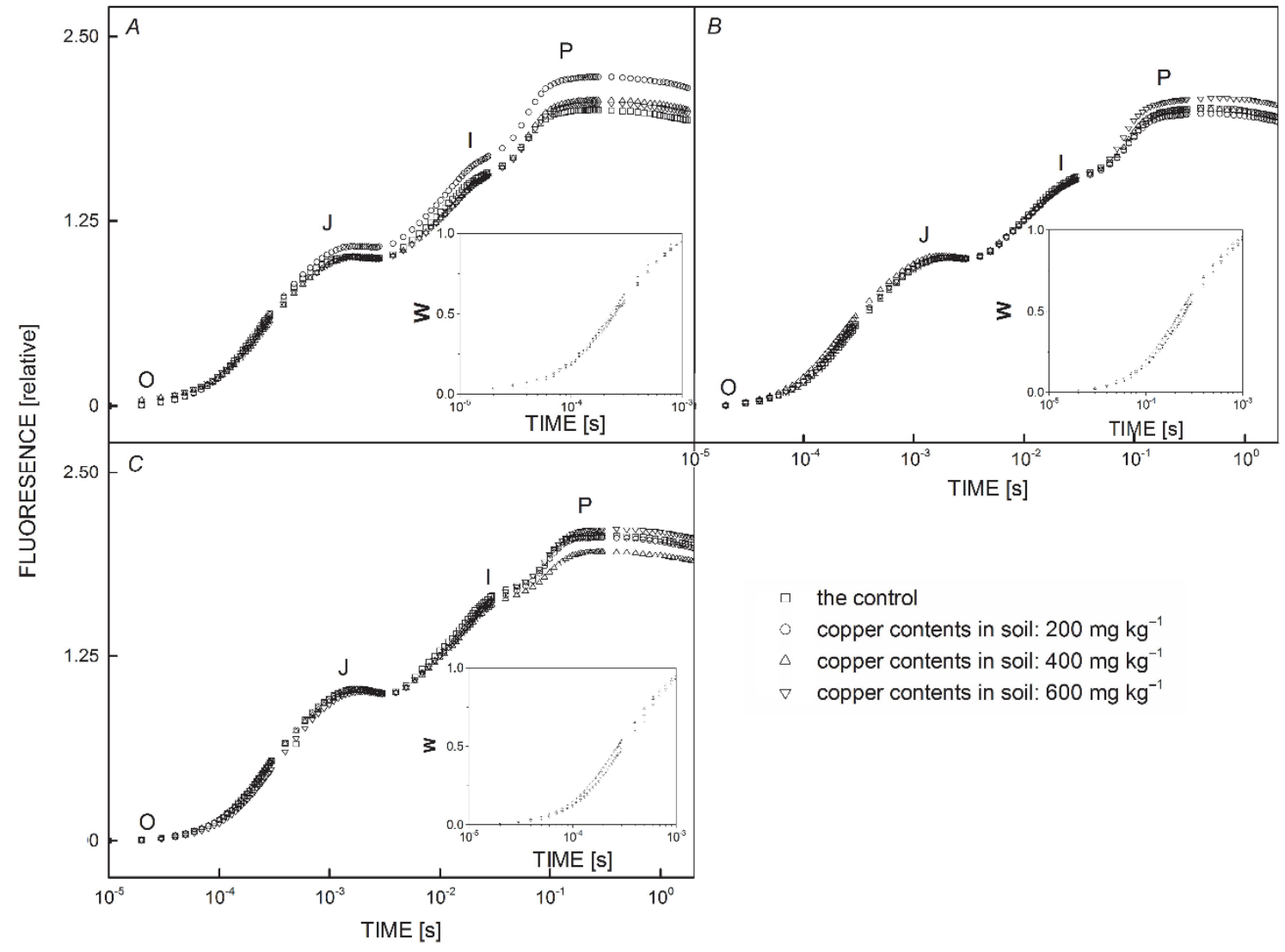

Fig. 3. Effects of soil $\mathrm{Cu}$ contamination on the OIJPs of Brassica chinensis (A), Chrysanthemum coronarium (B), and Brassica alboglabra $(C)$.

by pollutant (Susplugas et al. 2000, Appenroth et al. 2001). Strasser et al. (2000) and others (Susplugas et al. 2000, Appenroth et al. 2001, Meng et al. 2016) have defined the biological significance of these fluorescence parameters. The decrease of $\mathrm{F}_{\mathrm{v}} / \mathrm{F}_{\mathrm{m}}$ and $\mathrm{PI}_{\mathrm{abs}}$ may be considered as a potential indicator for environmental stress effects before appearance of visible physiological disturbances. Electron transport and energy fluxes are influenced due to the damage of PSII RCs under environmental stress (Strasser et al. 2000, Susplugas et al. 2000, Appenroth et al. 2001, Meng et al. 2016). The variation in an initial slope of the OJIP curve, $\varphi \mathrm{E}_{0}$ and $\psi \mathrm{E}_{0}$, which are induced by inhibition of electron transport of $\mathrm{Q}_{\mathrm{A}}-\mathrm{Q}_{\mathrm{B}}$ and $\mathrm{Q}_{\mathrm{A}}$ accumulation, may explain why the proportion of opened PSII RCs and the number of electrons used to carbon fixation (i.e., $P_{\mathrm{N}}$ ) is reduced and may also explain why the energy dissipated (Meng et al. 2016). In the present study, our results showed that all parameters of $\mathrm{Chl} a$ fluorescence were not significantly affected by the soil $\mathrm{Cu}$ contamination, i.e., the PSII function in all three vegetables were not significantly influenced. Our results are not similar to the results of Susplugas et al. (2000) or Appenroth et al. (2001), but partly similar to the results of Xia and Tian (2009).

All oxygenic photosynthetic plants investigated so far show a fluorescence rise consisting of a sequence of phases, labeled as $\mathrm{O}, \mathrm{J}, \mathrm{I}$, and $\mathrm{P}$, and this O-J-I-P polyphasic transient has been found to change its shape according to changes in environmental conditions (Susplugas et al. 2000, Appenroth et al. 2001). The K peak can appear in the OJIP under stressful conditions, e.g., high temperature, $\mathrm{Cr}$ contamination (Susplugas et al. 2000, Appenroth et al. 2001). In the present study, the results showed that all Chl $a$ fluorescence OJIPs produced normal OJIPs; no K peak appeared (Fig. 3). It indicates that the oxygen-evolving complex (OECs), or the organisations of the light-harvesting antenna (Susplugas et al. 2000) of the three vegetables were not damaged by soil $\mathrm{Cu}$ contamination. Our results are in disagreement to the results of Susplugas et al. (2000) or Appenroth et al. (2001).

Why was not the PSII function in all three vegetables significantly influenced by soil $\mathrm{Cu}$ contamination? It might be owing to a lower toxicity of $\mathrm{Cu}$ to plants in comparison to other pollutants. At low concentration, $\mathrm{Cu}$ is an essential element for plant growth and development. It plays an important role in many physiological processes, such as photosynthesis, respiration, carbohydrate distribution, $\mathrm{N}$ reduction and fixation, protein metabolism, etc. (Xu et al. 2006, Rai et al. 2016). Cu and $\mathrm{Zn}$, which either serve as cofactor or activators of enzyme reactions, e.g., in forming enzymes/substrate metal complex, are considered 


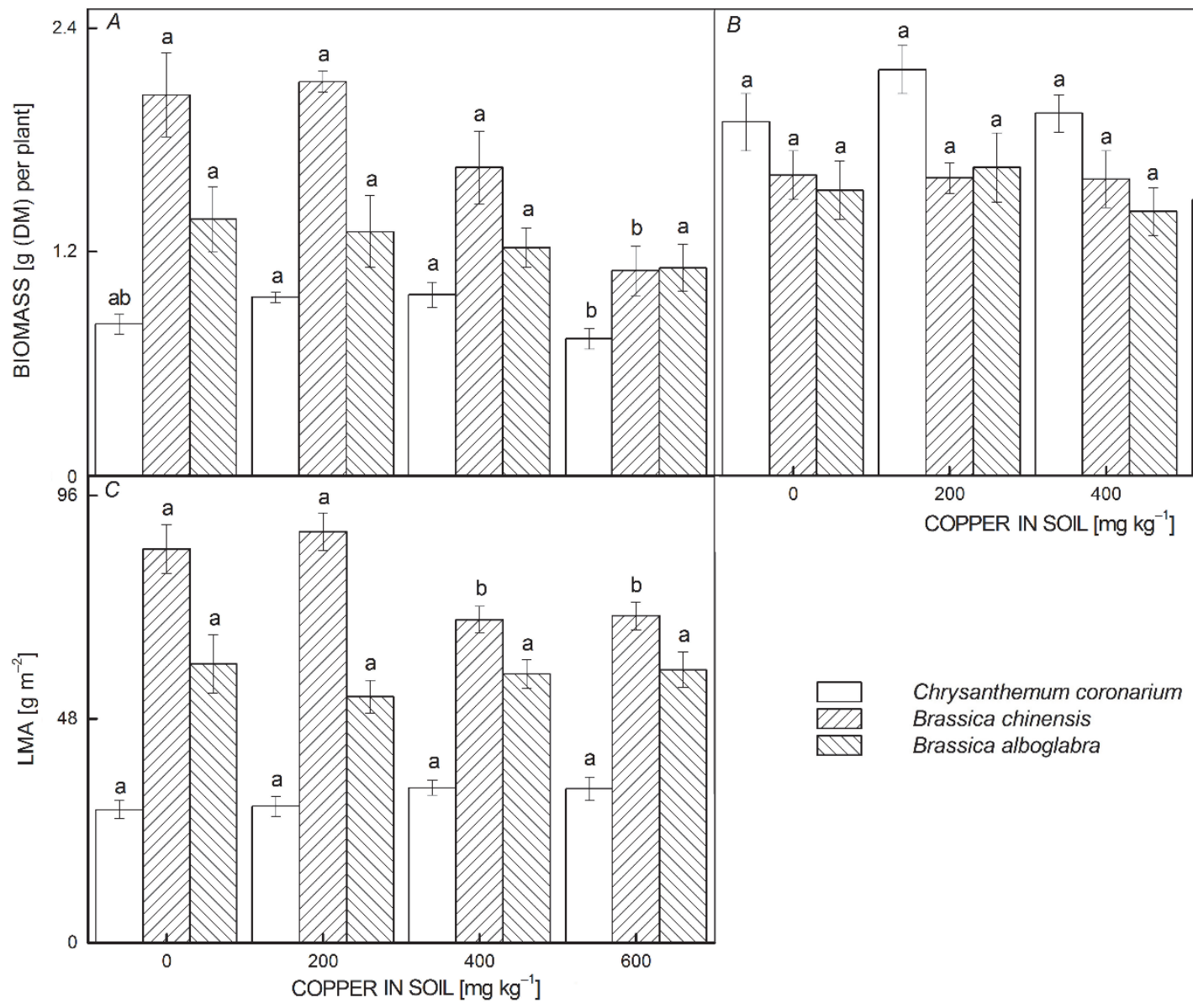

Fig. 4. Effects of soil $\mathrm{Cu}$ contamination on the biomass $(A)$, leaf area $(B)$, and leaf mass per area $(C)$ of three vegetables. Different lowercase letters show significant difference between different $\mathrm{Cu}$-contaminated groups at $P<0.05$, and, error bars show standard error (SE), $n=7$.

to be essential for plant growth. Therefore, heavy metal toxicity depends on plant species, specific metal, concentration, its chemical form, soil composition, and $\mathrm{pH}$ (Rai et al. 2016).

Plant growth: Soil pollution may inhibit the growth of plants. LA and LMA are often closely related to light conditions. Under low light, the LMA of Euonymus fortunei shows a decline, but the LA of $E$. fortunei shows an increase (Song and Li 2016). Compared with control, LA of T. platyphyllos was reduced by $29-60 \%$ which was associated with a level of pollution and irradiance as well, while the LMA exceeded the control by $4-25 \%$ at the most contaminated plots, but it diminished with an increasing distance from the pollution source (Lykholat et al. 2016).

In the present study, we showed that soil $\mathrm{Cu}$ contamination significantly decreased the biomass of $B$. chinensis and $C$. coronarium at the high $\mathrm{Cu}$ concentration, and significantly increased the biomass of C. coronarium at the low $\mathrm{Cu}$ concentration (Fig. 4A). The B. alboglabra might be less sensitive to the soil $\mathrm{Cu}$ contamination. The LMA of C. coronarium and B. alboglabra showed an upward trend with the increasing $\mathrm{Cu}$ contamination, while the LMA of $B$. chinensis showed a downward trend with the increasing $\mathrm{Cu}$, while the LA of the three vegetables showed a downward trend with the increasing $\mathrm{Cu}$ contamination (Fig. 4B,C). As mentioned above, variation in heavy metal toxicity depends on plant species and specific metal (Rai et al. 2016); thus, soil $\mathrm{Cu}$ contamination inhibited the growth of the three vegetables at different degrees.

Conclusions: The soil $\mathrm{Cu}$ contamination for the three plant types (Brassica chinensis, Chrysanthemum coronarium, Brassica alboglabra) showed the lower content of photosynthetic pigments, affected negatively photosynthesis, decreased the growth of vegetables. No significant influence on the PSII functions was observed due to the toxic performance of $\mathrm{Cu}$. 


\section{References}

Appenroth K.J., Stöckel J., Srivastava A. et al.: Multiple effects of chromate on the photosynthetic apparatus of Spirodela polyrhiza as probed by OJIP Chl $a$ fluorescence measurements. - Environ. Pollut. 115: 49-64, 2001.

Arnon I.D.: Copper enzymes in isolated chloroplasts. Polyphenoloxidase in Beta vulgaris. - Plant Physiol. 24: 1-15, 1949.

Capsi V., Droppa M., Horváth G. et al.: The effect of copper on Chl organization during greening of barley leaves. Photosynth. Res. 62: 165-174, 1999.

Chen C.T., Chen L.M., Lin C.C. et al.: Regulation of proline accumulation in detached rice leaves exposed to excess copper. - Plant Sci. 160: 283-290, 2001.

Chen H.Y., Teng Y.G., Lu S.J. et al.: Contamination features and health risk of soil heavy metals in China. - Sci. Total Environ. 512: 143-153, 2015.

da Costa M.V.J., Sharma P.K.: Effect of copper oxide nanoparticles on growth, morphology, photosynthesis, and antioxidant response in Oryza sativa. - Photosynthetica 54: 110119, 2016

Fu W.G., Wang F.K.: Effects of high soil lead concentration on photosynthetic gas exchange and Chl fluorescence in Brassica chinensis L. - Plant Soil Environ. 61: 316-321, 2015.

Guo R.F., Huang Z.K., Deng Y.P. et al.: Comparative transcriptome analyses reveal a special glucosinolate metabolism mechanism in Brassica alboglabra sprouts. - Front Plant Sci. 7: 1497, 2016.

Huang J.G.: [Trace elements nutrition and plant fertilizer.] - In: Huang J.G. (ed.): [Plant Nutrition.] Pp. 187-239. China Forestry Press, Beijing 2004. [In Chinese]

Kopsell D.A., Kopsell D.E., Lefsrud M.G.: Pre-harvest cultural growing conditions can influence carotenoid phytochemical concentrations in vegetable crops. - Acta Hortic. 841: 283-294, 2007.

Krupa Z., Skorzynska E., Maksymiec W. et al.: Effect of cadmium treatment on the photosynthetic apparatus and its photochemical activities in greening radish seedlings. Photosynthetica 21: 156-164, 1988.

Lichtenthaler H.K., Wellburn A.R.: Determinations of total carotenoids and Chl $a$ and $b$ of leaf extracts in different solvents. - Biochem. Soc. T. 11: 591 -592, 1983.

Lin M.Z., Lin N.W., Qiu X.F. et al.: [Wedelia trilobata's response to heavy metals and heavy metal absorption and enrichment in its body with sludge as a part of growth substrate.] - J. Anhui Agr. U. 39: 286-291, 2012a. [In Chinese]

Lin M.Z., Qiu X.F., Lin N.W. et al.: [Response of Alternanthera philoxeroides to heavy metals and its sorption effectiveness for heavy metals.] - Pratacult. Sci. 29: 681-686, 2012b. [In Chinese]

Lin M.Z., Wang Z.W., He L.C. et al.: Plant photosynthesisirradiance curve responses to pollution show non-competitive inhibited Michaelis kinetics. - PLoS ONE 10: e142712, 2015.

Lü C., Ren H., Zhang Y. et al.: Leaf area measurement based on image processing. - In: Lisa O. (ed.): 2010 International Conference on Measuring Technology and Mechatronics Automation. Pp. 580-582. IEEE Changsha 2010.

Lykholat Y., Alekseeva A., Khromykh N. et al.: Assesssment and prediction of viability and metabolic activity of Tilia platyphyllos in arid steppe climate of Ukraine. - Agricult. Forestry 62: 57-66, 2016.

Meng L.L., Song J.F., Wen J. et al.: Effects of drought stress on fluorescence characteristics of photosystem II in leaves of
Plectranthus scutellarioides. - Photosynthetica 54: 414-421, 2016.

Meng X.H., Zhang J.B., Li P. et al.: [Summary of livestock environmental pollution and environmental management policies.] - J. Ecol. Rural Environ. 30: 1-8, 2014. [In Chinese]

Mishra G., Zhang W., Deng F. et al.: A bifurcating pathway directs abscisic acid effects on stomatal closure and opening in Arabidopsis. - Science 312: 264-266, 2006.

Moussaoui F., Alaoui T.: Evaluation of antibacterial activity and synergistic effect between antibiotic and the essential oils of some medicinal plants. - Asian Pac. J. Trop. Med. 6: 32-37, 2016.

Planquart P., Bonin G., Prone A. et al.: Distribution, movement and plant availability of trace metals in soils amended with sewage sludge composts: application to low metal loadings. Sci. Total Environ. 241: 161-179, 1999.

Rai R., Agrawal M., Agrawal S.B.: Impact of heavy metals on physiological processes of plants: with special reference to photosynthetic system. - In: Singh A, Prasad S.M., Singh R.P. (ed.): Plant Responses to Xenobiotics. Pp. 127-140. Springer, Singapore 2016.

Razinger J., Dermastia M., Drinovec L. et al.: Antioxidative responses of duckweed (Lemna minor L.) to short-term copper exposure. - Environ. Sci. Pollut. R. 14: 194-201, 2007.

Razinger J., Drinovec L., Zrimec A.: Real-time visualization of oxidative stress in a floating macrophyte Lemna minor L. exposed to cadmium, copper, menadione, and AAPH. Environ. Toxicol. 25: 573-580, 2010.

Razinger J., Drinovec L., Berden-Zrimec M.: Delayed fluorescence imaging of photosynthesis inhibitor and heavy metal induced stress in potato. - Cent. Eur. J. Biol. 7: 531-541, 2012.

Sánchez Vilas J., Campoy J.G., Retuerto R.: Sex and heavy metals: Study of sexual dimorphism in response to soil pollution. - Environ. Exp. Bot. 126: 68-75, 2016.

Shi H.P., Zhu Y.F., Wang Y.L. et al.: Effect of cadmium on cytogenetic toxicity in hairy roots of Wedelia trilobata $\mathrm{L}$. and their alleviation by exogenous $\mathrm{CaCl}_{2}$. - Environ. Sci. Pollut. R. 21: 1436-1443, 2014.

Song X., Li H.: Effects of building shade on photosynthesis and Chl fluorescence of Euonymus fortunei. - Acta Ecol. Sin. 36: 350-355, 2016.

Stolpe C., Krämer U., Müller C.: Heavy metal (hyper) accumulation in leaves of Arabidopsis halleri is accompanied by a reduced performance of herbivores and shifts in leaf glucosinolate and element concentrations. - Environ. Exp. Bot. 133: 78-86, 2017.

Strasser R.J., Srivastava A., Tsimilli-Michael M.: The fluorescence transient as a tool to characterize and screen photosynthetic samples. - In: Yunus M., Pathre U., Mohanty P. (ed.): Probing Photosynthesis: Mechanism, Regulation \& Adaptation. Pp. 445-483. CRC Press, Boca Raton 2000.

Susplugas S., Srivastava A., Strasser R.J.: Changes in the photosynthetic activities during several stages of vegetative growth of Spirodela polyrhiza: effect of chromate. - J. Plant Physiol. 157: 503-512, 2000.

Tang X., Li X., Liu X. et al.: Effects of inorganic and organic amendments on the uptake of lead and trace elements by Brassica chinensis grown in an acidic red soil. - Chemosphere 119: 177-183, 2015.

Vinit-Dunand F., Epron D., Alaoui-Sossé B. et al.: Effects of copper on growth and on photosynthesis of mature and 
expanding leaves in cucumber plants. - Plant Sci. 163: 53-58, 2002.

Wang S.G.: Copper. - In: Wang S.G. (ed.): [Trace Elements and Physical Health.] Pp. 97-118. Shanghai Popular Sci. Press, Shanghai 2004. [In Chinese]

Wilson A., Ajlani G., Verbavatz J.M. et al.: A soluble carotenoid protein involved in phycobilisome-related energy dissipation in Cyanobacteria. - Plant Cell 18: 992-1007, 2006.

Xia J.R., Tian Q.R.: Early stage toxicity of excess copper to photosystem II of Chlorella pyrenoidosa-OJIP chlorophyll $a$ fluorescence analysis. - J. Environ. Sci. 21: 1569-1574, 2009.

Xu J., Yang L., Wang Z. et al.: Toxicity of copper on rice growth and accumulation of copper in rice grain in copper contaminated soil. - Chemosphere 62: 602-607, 2006.

Zeng X.B., Li L.F., Mei X.R.: [Heavy metal content in soils of vegetable-growing lands in China and source analysis.] - Sci. Agricult. Sin. 40: 2507-2517, 2007. [In Chinese]

Zupančič N.: Influence of climate factors on soil heavy metal content in Slovenia. - J. Soil Sediments 17: 1073-1083, 2016. 